\title{
Chemical composition and toxicity of the essential oil of Aloysia Paláu species (Verbenaceae) from South Brazil
}

\author{
Composição química e toxicidade do óleo essencial das espécies de Aloysia Paláu (Verbenaceae) do \\ Sul do Brasil
}

Composición química y toxicidad del aceite esencial de las especies de Aloysia Paláu (Verbenaceae)

del Sur de Brasil

Received: 10//08/2021 | Reviewed: 10//16/2021 | Accept: 01/13/2022 | Published: 01/15/2022

\author{
Eluíza Thomas \\ ORCID: https://orcid.org/0000-0003-2174-1337 \\ Universidade de Caxias do Sul, Brazil \\ E-mail: eluizathomas@gmail.com.br \\ Luciane Corbellini Rufatto \\ ORCID: https://orcid.org/0000-0002-1691-4566 \\ Universidade de Caxias do Sul, Brazil \\ E-mail: lurufatto@yahoo.com.br \\ Luciana Bavaresco Andrade \\ ORCID: https://orcid.org/0000-0003-0732-8714 \\ Universidade de Caxias do Sul, Brazil \\ E-mail: lbatougu@ucs.br \\ Priscila Ceribola Crespam \\ ORCID: https://orcid.org/0000-0002-0360-442X \\ Universidade Federal do Rio Grande do Sul, Brazil \\ E-mail: priscilacrespam@yahoo.com.br \\ Fabiana Agostini \\ ORCID: https://orcid.org/0000-0002-7627-1021 \\ Universidade de Caxias do Sul, Brazil \\ E-mail: mestrefabi@yahoo.com.br \\ Sidnei Moura \\ ORCID: https://orcid.org/0000-0003-1903-6735 \\ Universidade de Caxias do Sul, Brazil \\ E-mail: sidnei.moura@ucs.br \\ Joséli Schwambach \\ ORCID: https://orcid.org/0000-0001-6785-4164 \\ Universidade de Caxias do Sul, Brazil \\ E-mail: jschwambach@ucs.br
}

\begin{abstract}
In Brazil there are nine native species of Aloysia which are poorly studied as the chemical compositions and biological activities. Hence, this study describes the chemical composition determinated by GC-MS of essential oil of the five native and one cultivated species of Aloysia occurring in Rio Grande do Sul and evaluates the cytotoxic effects of the essential oils from A. citrodora, A. lycioides and A. dusenii through the bioassay with Artemia salina. A group of species showed 1,8-cineol as a major compound: A. dusenii (16.2\%), A. citrodora (32.8 \%), A. lycioides collected in Guaiba (49.5\%) and A. lycioides collected in São Marcos (17.6\%). While species A. polygalifolia and A. virgata had higher proportions of germacrene-D (11.2\% and $12 \%$, respectively) and A. chamaedryfolia presented spathulenol (15.6\%). The species A. lycioides collected in Rosário do Sul had $\beta$-Phellandrene (23.7 \%) as the major compound. All the essential oils tested presented a high toxicity against Artemia salina with LC $\mathrm{L}_{50}$ values among 48.12

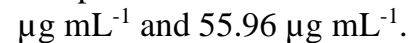

Keywords: Artemia salina; Hydrodistillation; Rio Grande do Sul.

\section{Resumo}

No Brasil existem nove espécies nativas de Aloysia que são pouco estudadas quanto às composições químicas e atividades biológicas. Assim, este estudo descreve a composição química determinada por CG-EM do óleo essencial de cinco espécies nativas e uma cultivada de Aloysia ocorrentes no Rio Grande do Sul e avalia a toxicidade dos óleos essenciais de A. citrodora, A. lycioides e A. dusenii através do bioensaio com Artemia salina. Um grupo de espécies apresentou 1,8-cineol como composto principal: A. dusenii (16,2\%), A. citrodora (32,8\%), A. lycioides coletada em 
Guaíba (49,5\%) e A. lycioides coletada em São Marcos (17,6\%). Enquanto as espécies A. polygalifolia e A. virgata apresentaram maiores proporções de germacreno-D (11,2\% e 12\%, respectivamente) e A. chamaedryfolia apresentou espatulenol (15,6\%). A espécie A. lycioides coletada em Rosário do Sul teve $\beta$-Felandreno (23,7\%) como composto majoritário. Todos os óleos essenciais testados apresentaram alta toxicidade contra Artemia salina com valores de CL50 entre $48,12 \mu \mathrm{g} \mathrm{mL}^{-1}$ e $55,96 \mu \mathrm{g} \mathrm{mL}^{-1}$.

Palavras-chave: Artemia salina; Hidrodestilação; Rio Grande do Sul.

\section{Resumen}

En Brasil existen nueve especies nativas de Aloysia que están poco estudiadas en cuanto a sus composiciones químicas y actividades biológicas. Por lo tanto, este estudio describe la composición química determinada por GC-MS del aceite esencial de cinco especies nativas y una cultivada de Aloysia que se encuentran en Rio Grande do Sul y evalúa la toxicidad de los aceites esenciales de A. citrodora, A. lycioides y A. dusenii mediante el bioensayo con Artemia salina. Un grupo de especies mostró 1,8-cineol como compuesto mayoritario: A. dusenii (16,2\%), A. citrodora (32,8\%), A. lycioides recolectada en Guaiba (49,5\%) y A. lycioides recolectada en São Marcos (17,6\%). Mientras que las especies $A$. polygalifolia y A. virgata presentaron mayores proporciones de germacreno-D (11,2\% y $12 \%$, respectivamente) y A. chamaedryfolia presentó espatulenol $(15,6 \%)$. La especie A. lycioides recolectada en Rosário do Sul tenía $\beta$-felandreno $(23,7 \%)$ como compuesto principal. Todos los aceites esenciales probados presentaron alta toxicidad contra Artemia salina con valores de LC50 entre $48.12 \mu \mathrm{g} \mathrm{mL}^{-1}$ y $55.96 \mu \mathrm{g} \mathrm{mL}^{-1}$.

Palabras clave: Artemia salina; Hidrodestilación; Rio Grande do Sul.

\section{Introduction}

Verbenaceae is a family of about 31 genera and approximately 918 species of herbs, shrubs, or small trees, mainly distributed in tropical and subtropical regions (Stevens, 2001). Among the most important genus are Lippia and Aloysia (Ricco et al, 2010). Aloysia comprises 30 species and is distributed from the South of the United States and Mexico until the north of Patagonia (Siedo, 2006), characterized by shrubby form, aromatic inflorescences, and known primarily for its essential oils (Hernandez et al, 2003). Nine species of Aloysia are native in Brazil, occurring all in the South region, and A. citrodora is found only under cultivation (Reflora, 2016).

Aromatic plants have been used since ancient times for their medicinal properties (Bakkali et al, 2008) and their odors are determined by the presence of essential oils (EOs), a mixture of volatile low-molecular-weight mono- and sesquiterpenes and other isoprenes (Singh et al, 2002). The EOs are involved in various ecological interactions including ones of medicinal properties such as bactericidal, fungicidal and antiviral properties (Chao et al, 2000), besides they may also exhibit cytotoxic activity (Sacchetti et al, 2005).

The brine shrimp lethality bioassay is rapid, simple, easily mastered, inexpensive, and requires small amounts of test material (Ghisalberti, 1993) to predict toxicity (McLaughlin, 1991). Since its introduction, this test has been successively employed to provide a frontline screen backed up by more specific and more sophisticated bioassays (Apu et al, 2010).

The present study reports the chemical composition by GC-MS of the essential oils of five native species of the genus Aloysia distributed in the Rio Grande do Sul - South Brazil and one cultivated species. Moreover, the cytotoxic activity of essential oil of the species A. citrodora, A. lycioides and A. dusenii were evaluated by brine shrimp bioassay.

\section{Methodology}

\subsection{Plant material}

Aerial parts from six species of Aloysia (leaves, flowers, and stem) were collected at seven locations in the Rio Grande do Sul State, Brazil (Table 1). The samples were identified, and voucher specimens were deposited in the Herbarium of the Universidade de Caxias do Sul (HUCS) and Herbarium of the Universidade Federal do Rio Grande do Sul (ICN). The detailed data referent to each species can be found in Table 1. 
Table 1. Location, Herbarium Number, and Collect Date of each specimens of Aloysia species used for chemical characterization.

\begin{tabular}{|c|c|c|c|}
\hline Plant Name & Location & Herbarium Number & Collect Date \\
\hline (I) Aloysia chamaedryfolia Cham. & 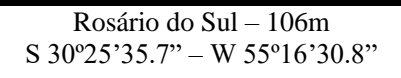 & HUCS 40702 & $\begin{array}{l}\text { April } \\
2013\end{array}$ \\
\hline (II) Aloysia citrodora Paláu & 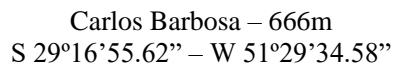 & HUCS 41907 & December 2013 \\
\hline (III) Aloysia dusenii Moldenke & $\begin{array}{c}\text { Garibaldi - } 48 \mathrm{~m} \\
\text { S 29¹3'58.51" - W } 51^{\circ} 39^{\prime} 48.02^{\prime \prime}\end{array}$ & HUCS 39692 & February 2014 \\
\hline (IV) Aloysia lycioides Cham. & 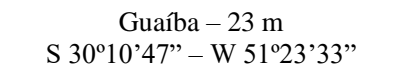 & HUCS 40700 & December 2012 \\
\hline (V) Aloysia lycioides Cham. & $\begin{array}{c}\text { São Marcos - } 746 \mathrm{~m} \\
\text { S 28 } 56^{\prime} 07.20^{\prime \prime}-\mathrm{W} 51^{\circ} 07^{\prime} 23.81^{\prime}\end{array}$ & HUCS 40699 & February 2013 \\
\hline (VI) Aloysia lycioides Cham. & $\begin{array}{c}\text { Rosário do Sul - } 106 \mathrm{~m} \\
\mathrm{~S} 30^{\circ} 25^{\prime} 35.7^{\prime \prime}-\mathrm{W} 55^{\circ} 16^{\prime} 30.8^{\prime \prime}\end{array}$ & HUCS 40703 & $\begin{array}{l}\text { April } \\
2013\end{array}$ \\
\hline (VII) Aloysia polygalifolia Cham. & $\begin{array}{c}\text { Guaíba }-23 \mathrm{~m} \\
\mathrm{~S} 30^{\circ} 10^{\prime} 47^{\prime \prime}-\mathrm{W} 51^{\circ} 233^{\prime},\end{array}$ & HUCS 40701 & December 2012 \\
\hline (VIII) Aloysia virgata (Ruiz \& Pav.) Juss. & $\begin{array}{c}\text { Três Passos - } 451 \mathrm{~m} \\
\mathrm{~S} 27^{\circ} 28^{\prime} 14^{\prime \prime}-\mathrm{W} 23^{\circ} 59^{\prime} 52^{\prime \prime}\end{array}$ & ICN 161927 & $\begin{array}{l}\text { April } \\
2014\end{array}$ \\
\hline
\end{tabular}

Source: Authors (2021).

\subsection{Essential oil extraction}

After collection, aerial parts of Aloysia species were dried at room temperature, fragmented, and subjected to extraction. Essential oils were obtained by hydrodistillation in a Clevenger apparatus for 1 hour (Agostini et al, 2009). Anhydrous sodium sulfate was employed to eliminate essential oil humidity. The essential oils were stored in airtight tubes, wrapped in aluminum foil, and stored in the freezer $\left(-20^{\circ} \mathrm{C}\right)$ prior to use.

\subsection{Essential oil chemical characterization}

Chromatographic analysis was performed using a gas chromatograph coupled to a mass spectrometer detector (GCMS) and a gas chromatograph with a flame ionization detector (GC-FID) (Hewlett Packard 6890) (Tomazoni et al, 2016). The analyses used two capillary columns HP-Innowax (GC-FID: $30 \mathrm{~m} \times 320 \mathrm{~mm} \times 0.50 \mathrm{~mm}$; GC-MS: $30 \mathrm{~m} \times 250 \mathrm{~mm} \times 0.50$ $\mathrm{mm})$, (Hewlett Packard, Palo Alto, USA). GC-MS analysis were carried out on the conditions: column temperature, $40{ }^{\circ} \mathrm{C}(8$ min) to $180{ }^{\circ} \mathrm{C}$ at $3{ }^{\circ} \mathrm{C} / \mathrm{min}, 180-230^{\circ} \mathrm{C}$ at $20^{\circ} \mathrm{C} / \mathrm{min}, 230^{\circ} \mathrm{C}(20 \mathrm{~min})$; interface $280{ }^{\circ} \mathrm{C}$; split ratio 1:100; carrier gas He (56 $\mathrm{KPa}$ ); flow rate: $1.0 \mathrm{~mL} / \mathrm{min}$; ionization energy $70 \mathrm{eV}$; mass range 40-350; volume injected $0.4 \mu \mathrm{L}$ diluted in hexane (1:10). GC-FID analyses were carried out on the conditions: column temperature, $40{ }^{\circ} \mathrm{C}(8 \mathrm{~min})$ to $180{ }^{\circ} \mathrm{C}$ at $3{ }^{\circ} \mathrm{C} / \mathrm{min}, 180-230{ }^{\circ} \mathrm{C}$ at $20{ }^{\circ} \mathrm{C} / \mathrm{min}, 230^{\circ} \mathrm{C}(20 \mathrm{~min})$; injector temperature $250^{\circ} \mathrm{C}$, detector temperature $250{ }^{\circ} \mathrm{C}$; split ratio 1:50; carrier gas $\mathrm{H}_{2}(34 \mathrm{KPa})$. The volume injected was $1 \mu \mathrm{L}$ diluted in hexane (1:10). Identification of the individual components was based on comparing their GC retention times (R.T.) on polar columns and comparison with mass spectra of components by GC-MS. The components were identified by a combination of the mass spectrum of Wiley library and by comparison with data from literature (Adams, 2007). The relative percentage of each component was obtained from chromatographic peak areas, assuming the sum of all eluted peaks was $100 \%$.

\subsection{Brine-shrimp bioassay}

The cytotoxicity bioassay was done according to Meyer's procedure (Meyer et al, 1982) with modifications on the preparation of the samples. The essential oils tested were obtained from A. citrodora, A. lycioides (V) and A. dusenii. 
Approximately $1 \mathrm{~g}$ brine shrimp eggs (Artemia salina - Flagner Soares de Souza Ind.) was hatched in a rectangular aquarium $(10 \times 20 \mathrm{~cm})$ filled with artificial seawater, which was prepared with $1 \mathrm{~L}$ beaker of distilled water containing $30 \mathrm{~g}$ of commercial salt mixture (Azevedo Bento S.A. Comércio e Indústria). After 48 hours of incubation, the active shrimp (10-15) were collected by pipette. The nauplii were transferred to culture plates with diluted solutions of the essential oils in $1000 \mu \mathrm{g}$ $\mathrm{mL}^{-1}, 500 \mu \mathrm{g} \mathrm{mL}^{-1}, 100 \mu \mathrm{g} \mathrm{mL}^{-1}, 50 \mu \mathrm{g} \mathrm{mL}{ }^{-1}$ e $20 \mu \mathrm{g} \mathrm{mL}^{-1}$ with dimethyl sulfoxide (DMSO) $1 \%$. The total volume was adjusted to $1 \mathrm{~mL}$ with artificial seawater. Three replications were done for each dose level and control with artificial seawater and DMSO 1\%. After 24 hours, the survivors were counted. The absence of movement of nauplii for 5 minutes was regarded as dead. The bioassay was done three times independently, and the $\mathrm{LC}_{50}$ (Lethal Concentration 50) and 95\% CI (Confidence Intervals) were calculated using the Probit Analysis with the software IBM SPSS 21.0.

\section{Results and Discussion}

\subsection{Chemical composition of the essential oils}

Essential oils of six species of Aloysia (Table 1) were analyzed for chemical composition by GC-MS. The essential

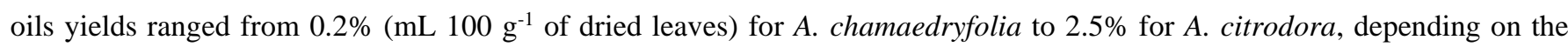
species (Table 2). But it also varied according to provenance from $0.8 \%$ for A. lycioides from Guaiba to $2.0 \%$ for A. lycioides from São Marcos (Table 2). A total of 25 (I), 36 (II), 23 (III), 16 (IV), 23 (V), 21 (VI), 13 (VII), and 26 (VIII) compounds were identified for each species or provenance, representing $56.1 \%$ to $88.4 \%$ of the composition of the essential oils (Table 2). 
Table 2. Chemical composition, chemical groups, and yield of essential oils from aerial parts of Aloysia species: (I) A. chamaedryfolia; (II) A. citrodora; (III) A. dusenii; (IV) A. lycioides collected in Guaíba; (V) A. lycioides collected in São Marcos; (VI) A. lycioides collected in Rosário do Sul, (VII) A. polygalifolia, (VIII) A. virgata.

\begin{tabular}{|c|c|c|c|c|c|c|c|c|c|}
\hline Compound & Group & 1 & II & III & IV & V & VI & VII & VIII \\
\hline a-Pinene & $\mathrm{HM}$ & 2.4 & 3.4 & 3.7 & 2.2 & 3.5 & 1.6 & - & 1.1 \\
\hline a-Thujene & $\mathrm{HM}$ & 0.2 & 0.2 & 0.6 & - & 0.7 & - & - & - \\
\hline Camphene & HM & - & 0.3 & - & - & - & - & - & - \\
\hline$\beta$-Pinene & $\mathrm{HM}$ & 3.3 & 0.2 & 13.0 & - & 11.6 & 1.2 & - & - \\
\hline $\beta$-Phellandrene & $\mathrm{HM}$ & 0.8 & 9.3 & 1.7 & - & 1.4 & 23.7 & - & - \\
\hline Myrcene & $\mathrm{HM}$ & 0.5 & 1.0 & 1.8 & - & 1.6 & - & - & - \\
\hline Limonene & HM & 1.2 & 6.0 & 9.9 & 2.9 & 8.6 & 0.4 & - & - \\
\hline 1,8-Cineol & OM & 3.1 & 32.8 & 16.2 & 49.5 & 17.6 & - & 2.1 & - \\
\hline$y$-Terpinene & HM & - & - & 1.8 & - & 0.6 & - & - & - \\
\hline p-Cymene & $\mathrm{HM}$ & 4,0 & 0.5 & 5.4 & 1.4 & 7.0 & 0.5 & - & - \\
\hline 1-Octadien-3-ol & OM & 0.1 & 0.5 & 0.2 & - & 0.1 & - & - & 0.4 \\
\hline$\Delta$-Elemene & $\mathrm{HS}$ & - & - & - & - & - & - & - & 1.5 \\
\hline Terpineol & OM & 0.2 & 2.2 & 0.3 & 2.4 & 0.5 & 1.5 & - & - \\
\hline a-Terpinene & OM & - & - & - & - & - & 0.4 & - & - \\
\hline a-Cedrene & HS & - & - & - & - & - & - & - & 0.6 \\
\hline$\beta$-Bourbonene & HS & 0.6 & 0.3 & - & - & - & - & 1.3 & 4.0 \\
\hline Linalool & OM & 7.7 & 0.7 & 1.8 & 1.5 & 2.1 & 1.8 & 0.8 & 0.5 \\
\hline Copaene & HS & - & - & - & - & - & 0.4 & - & - \\
\hline$\beta$-Cubebene & HS & - & - & - & - & - & - & - & 1.5 \\
\hline p-Caryophyllene & HS & - & - & - & - & - & - & - & - \\
\hline$\beta$-Caryophyllene & HS & 1.6 & 1.0 & 6.5 & 0.3 & 4.2 & 1.8 & 10.8 & 7.2 \\
\hline Terpinene-4-ol & OM & 0.5 & 0.5 & 1.4 & 1.4 & 1.3 & 1.8 & - & - \\
\hline Myrtenal & OM & 0.4 & - & - & - & - & - & - & - \\
\hline Alloaromadendrene & HS & - & - & - & - & - & - & - & 0.8 \\
\hline a-Caryophyllene & HS & 1.4 & 0.4 & 0.9 & - & 0.7 & 1.8 & 8.9 & 0.8 \\
\hline y-Murolene & HS & - & - & - & - & - & - & - & 1.1 \\
\hline cis-Verbenol & OM & - & - & - & 0.8 & - & - & - & - \\
\hline Myrtenyl Acetate & HS & 3.2 & - & - & - & - & - & - & - \\
\hline Germacrene-D & HS & 4.1 & 1.9 & 6.1 & - & 2.7 & 1.3 & 11.2 & 12.0 \\
\hline Bicyclogermacrene & HS & 3.3 & 3.1 & 4.3 & - & 2.0 & 0.6 & 1.7 & - \\
\hline Carvone & OM & - & - & - & - & - & - & 6.8 & - \\
\hline 8-isopropenyl-1,1,5-dimethy-5 iclocadiene & HS & - & - & - & 0.5 & - & - & - & - \\
\hline$\Delta$-3-Carene & $\mathrm{HM}$ & - & 0.3 & - & - & - & - & - & - \\
\hline$\beta$-Elemene & HS & - & - & - & - & - & - & - & 1.1 \\
\hline$\alpha$-Carene & $\mathrm{HM}$ & - & 3.2 & - & - & - & - & - & - \\
\hline Myrtenol & OM & 0.5 & - & - & - & - & - & - & - \\
\hline y-Elemene & HS & - & - & 0.2 & 0.6 & 0.2 & 0.4 & 1.4 & 7.1 \\
\hline p-Elemene & HS & 0.5 & - & - & - & - & - & - & - \\
\hline Menthadienol & OM & - & - & - & 0.4 & - & - & - & - \\
\hline a-Cubebene & $\mathrm{HS}$ & - & - & - & - & - & - & - & 2.6 \\
\hline$\Delta$-Cadinene & HS & 0.7 & 0.8 & 0.2 & 0.7 & 0.4 & 0.8 & - & - \\
\hline Caryophyllene Oxide & OM & 4.6 & 1.8 & 5.4 & 3.6 & 8.3 & 8.7 & 7.8 & 3.2 \\
\hline Epibiciclo-sesquiphelandrene & HS & - & - & - & - & - & - & - & 2.3 \\
\hline Nerolidol & OS & - & 0.6 & - & - & - & 4.6 & 1.1 & 1.6 \\
\hline Elemol & os & 0.9 & - & 4.4 & - & 4.7 & 1.0 & 0.6 & - \\
\hline a-Elemol & os & - & - & - & - & - & 15.3 & - & - \\
\hline a-Selinene & HS & - & 0.3 & - & - & - & - & - & - \\
\hline Guaiol & os & - & - & - & - & - & - & - & 1.6 \\
\hline Cedrol & OS & - & 10.3 & 0.1 & 2.3 & 0.2 & - & 1.5 & 1.7 \\
\hline (-) Spathulenol & os & 15.7 & 3.1 & 2.6 & 6.3 & 4.9 & 0.6 & - & 4.9 \\
\hline Calarene & HS & - & - & - & - & - & - & - & 1.0 \\
\hline$\beta$-Patchoulene & HS & - & - & - & - & - & - & - & 1.5 \\
\hline Bulnesol & os & - & - & - & - & - & - & - & 0.9 \\
\hline (+) Spathulenol & os & - & - & - & - & - & - & - & 10.6 \\
\hline Caryophylladienol & OS & - & - & - & - & - & - & - & 1.1 \\
\hline $\begin{array}{l}\text { Total identified } \\
\text { Oil yield v/p (\%) }\end{array}$ & & $\begin{array}{c}61.5 \\
0.2\end{array}$ & $\begin{array}{c}84.7 \\
2.5\end{array}$ & $\begin{array}{c}88.5 \\
1.1\end{array}$ & $\begin{array}{c}76.8 \\
0.8\end{array}$ & $\begin{array}{c}84.9 \\
2.0\end{array}$ & $\begin{array}{c}70.2 \\
1.0\end{array}$ & $\begin{array}{c}56.0 \\
0.4\end{array}$ & $\begin{array}{c}72.7 \\
0.8\end{array}$ \\
\hline
\end{tabular}


The main compounds of each EO showed that each species presented a different composition. However, some constituents are conserved in several species, as linalool and ß-caryophyllene, for example (Table 2). Possibly, the conservation of these constituents may have chemotaxonomic significance to maintain similar morphologic and biochemical characteristics, which will determine the biosynthesis of their secondary metabolism (Sousa et al, 2012). For A. lycioides, collections were performed in three different locations and resulted in different chemical compositions. Thereby, these species were separated into two groups: major compound 1,8-cineol (IV and V) and $\beta$-Phellandrene (VI). These differences in major compounds found among the A.lycioides from Guaíba and São Marcos and from Rosário do Sul could be associated with the geographical origin of the material, but could also suggest different chemotypes. The species A. citrodora is known for the predominant presence of citral in their chemical composition (Zigadlo et al, 1994). However, our results did not show the presence of this component. These data may suggest a new chemotype for the species. These results are based on a local collection and do not analyze the intraspecific variation. The different chemistry can occur through the influence of environmental conditions and seasonal variations (Ricciardi et al, 2011). On the other hand, the composition of the essential oil of a plant is also genetically determined and usually specific to a particular organ and characteristic for their stage of development, giving rise to chemotypes in plants rich in essential oils. Tavares et al (2005) showed that differences in the composition of different chemotypes of Lippia alba are not only a product of the influence of environmental factors but mainly reflect the genotypic variation of these plants.

There were predominant monoterpenes (Table 3) in A. citrodora (59.6\%), A. dusenii (63.1\%), and A. lycioides (collected in Guaíba 66.7\%, collected in São Marcos 65.1\%, and collected in Rosário do Sul 41.3\%). The species A. virgata and A. polygalifolia showed higher levels of sesquiterpenes ( $45.4 \%$ and $66.1 \%$, respectively), while A. chamaedryfolia presented a similar quantity of mono- and sesquiterpenes (29.4\% and 28,9\%, respectively). These classes of terpenes are related to different biological activities (Singh \& Sharma 2015) what can explain the popular use of some Aloysia species for medicinal purposes (Santos et al, 2015).

Table 3. Percentage of chemical groups (mono- and sesquiterpenes) in essential oils from Aloysia species: (I) A. chamaedryfolia; (II) A. citrodora; (III) A. dusenii; (IV) A. lycioides collected in Guaíba; (V) A. lycioides collected in São Marcos; (VI) A. lycioides collected in Rosário do Sul, (VII) A. polygalifolia, (VIII) A. virgata.

\begin{tabular}{|c|c|c|c|c|c|c|c|c|}
\hline Chemical groups & I & II & III & IV & $\mathbf{V}$ & VI & VII & VIII \\
\hline Hydrocarbon monoterpenes & 12.4 & 21.2 & 37.8 & 6.5 & 35.1 & 27.5 & 0.0 & 2.2 \\
\hline Oxygenated monoterpenes & 17.1 & 38.4 & 25.3 & 60.2 & 30.0 & 13.8 & 10.6 & 4.7 \\
\hline Total Monoterpenes & 29.4 & 59.6 & 63.1 & 66.7 & 65.1 & 41.3 & 10.6 & 6.9 \\
\hline Oxygenated sesquiterpenes & 15.6 & 14.4 & 2.7 & 8.6 & 5.1 & 20.5 & 2.6 & 22.6 \\
\hline Total sesquiterpenes & 28.9 & 25.1 & 25.3 & 10.1 & 20.1 & 29.0 & 45.4 & 66.1 \\
\hline
\end{tabular}

Source: Authors (2021).

\subsection{Cytotoxicity activities}

As expected, the degree of lethality was directly proportional to the essential oil concentration (Table 4). The mortality rate of brine shrimp nauplii was drastically increased as the dose level was increased from $20 \mu \mathrm{g} \mathrm{mL}^{-1}$ to $100 \mu \mathrm{g} \mathrm{mL}$ ${ }^{1}$. Moreover, a $100 \%$ mortality was observed at $500 \mu \mathrm{g} \mathrm{mL}^{-1}$ and $1000 \mu \mathrm{g} \mathrm{mL}^{-1}$ dose levels for all essential oil evaluated. More than $80 \%$ of the nauplii remained active in control, with DMSO $1 \%$. 
Table 4. Toxicity of essential oils from Aloysia species on Artemia salina in different doses level with their LC 50 and $95 \%$ confidence intervals determined by Probit Analysis.

\begin{tabular}{|c|c|c|c|c|c|c|c|c|}
\hline \multirow{2}{*}{ Species } & \multicolumn{6}{|c|}{ Percentage of death at 24 hours/dose $\left(\mu \mathrm{g} \mathrm{mL}^{-1}\right)$} & \multirow{2}{*}{$\operatorname{LC50}\left(\mu \mathrm{g} \mathbf{~ m L}^{-1}\right)$} & \multirow{2}{*}{$95 \% \mathrm{CI}\left(\mu \mathrm{g} \mathrm{mL} \mathbf{L}^{-1}\right)$} \\
\hline & 1000 & 500 & 100 & 50 & 20 & Control & & \\
\hline A. citrodora & 100.00 & 100.00 & 75.33 & 32.41 & 25.20 & 15.26 & 55.96 & $45.97-67.49$ \\
\hline A. dusenii & 100.00 & 99.62 & 74.89 & 37.45 & 29.88 & 13.72 & 48.98 & $43.74-54.58$ \\
\hline A. lycioides & 100.00 & 99.82 & 73.73 & 35.25 & 33.60 & 14.35 & 48.12 & $40.10-57.14$ \\
\hline
\end{tabular}

Source: Authors (2021).

The value of $\mathrm{LC}_{50}$, calculated from the 24-hour counts, was not different among the essential oils of the species tested. Therefore, the toxicity was considered high, and $\mathrm{LC}_{50}$ values were from $48.12 \mu \mathrm{g} \mathrm{mL}^{-1}$ in A. lycioides (V) to $55.96 \mu \mathrm{g} \mathrm{mL}{ }^{-1}$ in A. citrodora. The similar toxicity of these essential oils can probably be explained by the main constituent, 1.8-cineol, present in all of them. According to Meyer et al (1982) the $\mathrm{LC}_{50}$ value under $1000 \mu \mathrm{g} \mathrm{mL}^{-1}$ is pharmacologically active and toxic, classifying these as potentially of pharmacological interest as some authors have already related the brine shrimp lethality with the detection of antitumoral compounds in terrestrial plants (Carballo et al, 2002, Mackeen et al, 2000). However, there is no correlation between the degree of toxicity found for brine shrimp and the toxicity to mammalian cells and the brine shrimp test is used as a tool for approaching the real toxicity (Oliva et al, 2007). Oliva et al (2007) showed in their study the low toxicity of the essential oil from Aloysia tomentosa $\left(\mathrm{LC}_{50} 968 \mu \mathrm{g} \mathrm{mL}-1\right.$ ), and nontoxicity of essential oils from Aloysia polystachia $\left(\mathrm{LC}_{50} 6459 \mu \mathrm{g} \mathrm{mL}^{-1}\right.$ ) and Aloysia triphylla (synonym for A. citrodora) ( $\mathrm{LC}_{50} 1279 \mu \mathrm{g} \mathrm{mL}^{-1}$ ), differently of the high toxicity observed in this work for all species, especially A. citrodora. Nevertheless, the essential oil composition determined by them for A. triphylla (A. citrodora) was different and rich in limonene, citral, spathulenol, and thujone, showing the importance of chemical characterization to study biological activities.

\section{Conclusion}

This work is the first study evaluating the chemical composition of the essential oil of six species of Aloysia from the South of Brazil. The species showed different chemical compositions, but some constituents are conserved in several species. This chemical information can assist in the taxonomy of the genus. Also, the results demonstrated the cytotoxic activity of some Aloysia essential oils, showing that studies like this are essential in the screening for new substances with potential biological activities. Therefore, the following steps should be a more detailed evaluation of the toxicity presented by this essential oil to secure the safety of using these natural products.

\section{Acknowledgments}

This study was supported by Coordenação de Aperfeiçoamento de Pessoal de Ensino Superior (1162577). We want to thank Nelson Ivo Matzenbacher for sharing knowledge and helping with the collection of A. polyfgalifolia. Also, we would like to thank Diego Maciel and Felipe Gonzatti for helping collect A. virgata and A. dusenii, respectively.

\section{References}

Adams, R. P. (2007). Identification of Essential Oil Components by Gas Chromatography/Mass Spectroscopy. (4th ed). Allure Publishing Corporation.

Agotini, F., Santos, A. C. A., Rossato, M., Pansera, M. R., Santos, P. L., Serafini, L. A., Molon, R. \& Moyna, P. (2009). Essential oil yield and composition of Lamiaceae species growing in Southern Brazil. Brazilian Archives of Biology and Technology, 52(2), 473-478. https://doi.org/10.1590/S151689132009000200026

Apu, A., Muhit, M., Tareq, S., Pathan, A., Jamaluddin, A. \& Ahmed, M. (2010). Antimicrobial activity and brine shrimp lethality bioassay of the leaves extract of Dillenia indica Linn. Journal of Young Pharmacists, 2(1), 50-53. https://doi.org/10.4103/0975-1483.62213 
Bakkali, F., Averbeck, S., Averbeck, D. \& Idaomar, M. (2008). Biological effects of essential oils - a review. Food and Chemical Toxicology, 46(2), 446-475. https://doi.org/10.1016/j.fct.2007.09.106

Carballo, J.L., Hernandez-Inda, Z. L., Pilar, P. \& Garcia-Gravalos, M. D. (2002). A comparison between two brine shrimp assays to detect in vitro cytotoxicity in marine natural products. BMC Biotechnology, 2,17. https://bmcbiotechnol.biomedcentral.com/articles/10.1186/1472-6750-2-17

Chao, S. C., Young D. G. \& Oberg, C. J. (2000). Screening for inhibitory activity of essential oils on selected bacteria, fungi and viruses. Journal of Essential Oil Research, 12(5), 639-649. https://doi.org/10.1080/10412905.2000.9712177

Ghisalberti, E. L. (1993). Detection and isolation of bioactive natural products. In S.M, Colegate. \& R.J, Molyneux (Ed.). Bioactive Natural products: Detection, Isolation and Structure Elucidation ( $2^{\text {nd }}$ ed.), 15-18. Boca Raton: CRC Press.

Hernandez, T., Canales, M., Avila, J. G., Duran, A., Caballero J., Romo de Vivar, A. \& Lira, R. (2003). Ethnobotany and antibacterial activity of some plants used in traditional medicine of Zapotitlán de las Salinas, Puebla (Mexico). Journal of Ethnopharmacology, 88(2-3), 181-188. https://doi.org/10.1016/S03788741(03)00213-7

Khafagi, I., Dewedar, A. \& Farouk, S. (2000). In vitro cytotoxicity and antimicrobial activities of some common essential oils. Egyptian Journal of Biology, 2, 20-27. https://www.ajol.info/index.php/ejb/article/view/29900

Mackeen, M. M., Ali, A. M., Lajis, N. H., Kawazu, K., Hassan, Z., Amran, M., Habsah, M., Mooi, L.Y. \& Mohamed, S. M. (2000). Antimicrobial, antioxidant, antitumour-promoting and cytotoxic activities of different plant part extracts of Garcinia atroviridis Griff. Ex T. Anders. Journal of Ethnopharmacology, 72,395-402. https://doi.org/10.1016/S0378-8741(00)00245-2

McLaughlin, J. L. (1991). Assays for bioactivity. In K, Hostettmann (Ed.). Methods in Plant Biochemistry (pp. 1-33). Academic Press.

Meyer, B. N., Ferrigni, N. R., Putnam, J. E., Jacobsen, L. B., Nichols, D. E. \& McLaughlin, J. L. (1982). Brine shrimp: a convenient general bioassay for active plant constituents. Planta Medica, 45(5), 31-34. 10.1055/s-2007-971236

Oliva, M. M., Gallucci, N., Zygadlo, J. A. \& Demo, M. S. (2007). Cytotoxic Activity of Argentinean Essential Oils on Artemia salina., Pharmaceutical Biology, 45(4), 259-262. 10.1080/13880200701214557

Reflora - Herbário Virtual. (2016). http://reflora.jbrj.gov.br/reflora/herbarioVirtual/

Ricciardi, G., Torres, A. M., Bubenik, A. L., Ricciardi, A., Lorenzo, D. \& Dellacassa, E. (2011). Environmental effect on essential oil composition of Aloysia citriodora from Corrientes (Argentina). Natural Product Communications, 6(11), 1711-1714. 10.1177/1934578X1100601135

Ricco, R. A., Wagner, M. L., Portmann, E., Reides, C., Llesuy, S., Gurni, A. A. \& Carballo, M. A. (2010). Survey on polyphenols, antioxidant activity and genotoxicity on Argentinean species of Lippia and Aloysia (Verbenaceae). Boletim Latinoamericano e do Caribe de Plantas Medicinais e Aromáticas, 9(5), 388-396. https://www.redalyc.org/pdf/856/85615225010.pdf

Sacchetti, G., Maietti, S., Muzzoli, M., Scaglianti, M., Manfredini, S., Radice, M. \& Bruni, R. (2005). Comparative evaluation of 11 essential oils of different origin as functional antioxidants, antiradicals and antimicrobial in food. Food Chemistry, 91(4), 621-632. https://doi.org/10.1016/j.foodchem.2004.06.031

Santos, A. C. B., Nunes, T. S., Coutinho, T. S. \& Silva, M. A. P. (2015). Uso popular de espécies medicinais da família Verbenaceae no Brasil. Revista Brasileira de Plantas Medicinais. 17(4-II), 980-991. https://doi.org/10.1590/1983-084X/14_083

Siedo, S. J. (2006). Systematics of Aloysia (Verbenaceae). [dissertation]. Texas (TX): University of Texas at Austin. https://repositories.lib.utexas.edu/handle/2152/3492

Singh, B. \& Sharma, R. A. (2015). Plant terpenes: defense responses, phylogenetic analysis, regulation and clinical applications. 3 Biotech 5, 129-151. https://doi.org/10.1007/s13205-014-0220-2

Singh, H. P., Batish, D. R., Kaur, S. \& Kohli, R. K. (2002). Allelopathic effect of two volatile monoterpenes against bill goat weed (Ageratum conyzoides L.). Crop Protection, 21(4), 347-350. https://doi.org/10.1016/S0261-2194(01)00096-5

Sousa, O. V., Del-Vechio-Vieira, G., Alves, M. S., Aílson, A. L. A., Pinto, M. A. O., Amaral, M. P. H., Rodarte, M. P. \& Kaplan, M. A. C. (2012). Chemical composition and biological activities of the essential oils from Dauguetia lanceolata St. Hil. Barks. Molecules, 17(9), 11056-11066. 10.3390/molecules 170911056

Stevens, P. F. (2001). Angiosperm Phylogeny Website. Version 14, July 2017. http://www.mobot.org/MOBOT/research/APweb/

Tavares, E. S., Julião, L. S., Lopes, D., Bizzo, H. R., Lage, C. L. S. \& Leitão, S. G. (2005). Analysis of the essential oil from leaves of three Lippia alba (Mill.) N. E. Br. (Verbenaceae) chemotypes cultivated on the same conditions. Brazilian Journal of Pharmacognosy, 15(1), 1-5. https://doi.org/10.1590/S0102$695 \times 2005000100002$

Tomazoni, E. Z., Pansera, M. R., Pauletti, G. F., Moura, S., Ribeiro, R. S. T. \& Schwambach, J. (2016). In vitro antifungal activity of four chemotypes of Lippia alba (Verbenaceae) essential oils against Alternaria solani (Pleosporeaceae) isolates. Anais da Academia Brasileira de Ciências, 88(2), 999-1010. http://dx.doi.org/10.1590/0001-3765201620150019

Zigadlo, J. A., Lamarque, L. A., Maestri, D. M., Guzmán, C. A., Lucini, E. I., Grosso, N. R. \& Ariza-Espinar, L. (1994). Volatile Constituents of A. triphylla (L'Herit.) Britton. Journal of Essential Oil Research, 6(4), 407-409. https://doi.org/10.1080/10412905.1994.9698409 